\title{
Rootstock breeding in Prunus species: Ongoing efforts and new challenges
}

\author{
Felipe Gainza $^{*}$, Ismael Opazo ${ }^{1}$, Verónica Guajardo ${ }^{1}$, Pablo Meza ${ }^{2}$, Mauricio Ortiz ${ }^{1}$, Jorge Pinochet ${ }^{1}$, \\ and Carlos Muñoz ${ }^{3}$
}

The current global agricultural challenges imply the need to generate new technologies and farming systems. In this context, rootstocks are an essential component in modern agriculture. Most currently used are those clonally propagated and there are several ongoing efforts to develop this type of plant material. Despite this tendency, lesser number of rootstock breeding programs exists in comparison to the large number of breeding programs for scion cultivars. In the case of rootstocks, traits evaluated in new selection lines are quite different: From the agronomic standpoint vigor is a key issue in order to establish high-density orchards. Other important agronomic traits include compatibility with a wide spectrum of cultivars from different species, good tolerance to root hypoxia, water use efficiency, aptitude to extract or exclude certain soil nutrients, and tolerance to soil or water salinity. Biotic stresses are also important: Resistance/tolerance to pests and diseases, such as nematodes, soil-borne fungi, crown gall, bacterial canker, and several virus, viroids, and phytoplasms. In this sense, the creation of new rootstocks at Centro de Estudios Avanzados en Fruticultura (CEAF) offers an alternative to stone fruit crop, particularly in Chile, where just a few alternatives are commercially available, and there are site-specific problems. The implementation of molecular markers in order to give support to the phenotypic evaluation of plant breeding has great potential assisting the selection of new genotypes of rootstocks. Marker-Assisted Selection (MAS) can shorten the time required to obtain new cultivars and can make the process more cost-effective than selection based exclusively on phenotype, but more basic research is needed to well understood the molecular and physiological mechanisms behind the studied trait.

Key words: Abiotic stress, biotic stress, breeding technique, clonal rootstocks, resistance, stone fruit crops, tolerance.

\section{INTRODUCTION}

Rootstocks are an essential component in modern fruit production because of their capability of adapting a particular cultivar to diverse environmental conditions and cultural practices. Rootstocks can provide several or many traits that are absent in the scion, such as soil's pest and disease resistance, better anchorage, improved nutrient uptake, better tolerance to soils with high saline content or drought, as well as other limiting soil conditions. On the other hand, they can modify the performance of scion, like for example, by reducing tree vigor, and modify canopy structure that would allow the establishment of high density orchards. Rootstocks can

${ }^{1}$ Centro de Estudios Avanzados en Fruticultura (CEAF), Camino Las Parcelas 882, sector Los Choapinos, Rengo, Chile.

*Corresponding author (fgainza@ceaf.cl).

${ }^{2}$ Instituto de Investigaciones Agropecuarias, INIA La Platina, Santa Rosa 11610, La Pintana, Santiago, Chile.

${ }^{3}$ Universidad de Chile, Facultad de Ciencias Agronómicas, Santa

Rosa 11315, La Pintana, Santiago, Chile.

Received: 8 December 2014.

Accepted: 25 April 2015.

doi:10.4067/S0718-58392015000300002 also reduce or extend the fruit maturation period; improve yield and fruit quality increasing profit returns. Therefore, each particular rootstock/scion combination can generate a plant with characteristic that neither component exhibits if grown separately.

Grafting was the key technological development that enabled the extensive use of rootstocks at present, which goes beyond fruit culture (Kubota et al., 2008).

The ways in which rootstock and scion interact to produce a variety of effects that modify the performance of the whole combination is well documented, has profound economic effects, and are generally referred to as rootstock/scion relationships. However, the mechanisms of these relationships are complex and partially understood.

There is a limit on the possibilities for making rootstock/scion combinations, since combinations beyond the species are generally not possible due to several incompatibility factors that prevent forming a solid and durable graft union. A degree of taxonomic relatedness should exist for the success of a particular rootstock/ scion combination. Consequently, the degree of success goes as follows: intraclonal $>$ interclonal $>$ intraspecific $>$ interspecific $>$ intrageneric $>$ intergeneric $>$ intrafamilial (Andrews and Serrano, 1993). 
Rootstocks currently available for fruit species are of two types: (1) Seedling rootstocks, which are those arising from a germinated seed of a particular cultivar. They are easy and almost inexpensive to propagate and are probably still the most widely used method. They have the additional advantage that they are free of those viruses that are not seed propagated (Mink, 1993). A lot of seedling rootstocks, however, have the disadvantage of presenting genetic variability, which leads to an uneven performance on grafted trees in the orchard. This variability can affect important agronomic characteristics such as vigor, productivity and other traits, including those for which the rootstock was selected. (2) Clonal rootstocks are those obtained from selected individuals that are vegetative propagated resulting in individuals with the exact genetic composition. They have the advantage of generating uniform orchards, easier to manage and more productive. Clonal rootstocks can be propagated by in vitro techniques, rooted cuttings or layering (Hartmann et al., 2002).

Seed propagated rootstocks were the most widely used alternative during the early development of modern fruit culture. Today however, clonally propagated cultivars are preferred for most species. According to Cummins and Aldwinckle (1995), the first commercial development of clonal rootstocks began in apples to control tree vigor and incorporate resistance to the woolly apple aphid (Eriosoma lanigerum Hausmn.) This development took place 1922 at the John Innes Institute in cooperation with the East Malling Research Station, UK, which led to the release of the Merton Immune and the Malling-Merton series. Because of its great impact in apple culture, this initial development stimulated the initiation of similar programs for other fruit crops, like grapes (Whiting, 2004), cherries (Perry, 1987), and more recently Prunus (Rom and Carlson, 1987). Today there are several ongoing efforts to develop clonal rootstocks for many fruit crops. Despite this new tendency, lesser number of rootstock breeding programs exists in comparison to the large number of breeding programs for scion cultivars. These is probably due to the fact that rootstock programs are more expensive, long term; and require a large and well coordinated multidisciplinary effort. They also differ from scion program in the fact that released cultivars have a longer lifespan in comparison with scion cultivars, which become obsolete in a shorter period of time. Rootstock royalties collected by the breeder also tend to be much lower which in contrast, is not the case for scion cultivars. For these main reasons most rootstock programs are publicly funded.

In general, breeding programs for rootstocks use the similar methods than those implemented for obtaining scion cultivars. However, they differ in their strategy. Rootstock breeding programs make an extensive use of interspecific hybridization to broaden the genetic base, allowing the introgression of genes generally not present in the breeding population. Since many interspecific hybrids obtained are not fertile, the $F_{1}$ population is the preferred population for testing, so the number of interspecific hybrids obtained in a given program is very important. Also, the traits that are evaluated are quite different: From the agronomic standpoint vigor is a key issue, in some species to enhance vigor, and in others, to control vigor allowing the establishment of high-density orchards.

Other important agronomic traits include the compatibility with a wide spectrum of cultivars from different species, a good aptitude for clonal propagation, modified chill requirements, tolerance to extreme temperatures and to root hypoxia, efficiency in the use of water, aptitude to extract or exclude certain soil nutrients, and tolerance to soil or water salinity. Biotic stresses are also important: Resistance/tolerance to pests, such as woolly aphids (pome fruits crops), Phylloxera (grapes), and nematodes which are problematic in most fruits species. In the case of Prunus, root-knot nematodes (Meloidogyne spp.) and lesion nematodes (Pratylenchus spp.) are the most damaging nematode pathogens. Also, resistance and/or tolerance is needed for diseases caused by a number of soil-borne fungi, crown gall (Agrobacterium tumefaciens), bacterial canker (Pseudomonas siringae pv. siringae), and several virus, viroids, and phytoplasms. The aim of this review was have an overall point of view about the most recent advances in each trait in which the CEAF rootstock breeding program is currently focused.

\section{BREEDING FOR SPECIFIC OBJECTIVES}

\section{Vigor control}

Rootstocks modify size and shape of the trees by shortening internodes size, altering the angle of the branches, dates and rates of active growth. A dwarfing rootstock is the one capable of suppressing growth of the grafted variety, as compared to growth of that variety on its own roots (Webster, 1995). In peach, rootstocks can induce or modify trunk cross-sectional area (TCSA), plant height, canopy volume, structure of branching, emission of suckers, fruit size, and production efficiency (Layne, 1994), as well as distribution of the dry matter and starch contents in old and new branches, both in winter dormancy and in active growth conditions (Caruso et al., 1997). The parameter TCSA is normally used to estimate tree vigor, but not always reflects well the true vigor of a tree, thus the need complement with other criteria such as tree height and canopy volume (Webster, 1995). The rootstock also modifies the concentration of nutrients in leaves and stems. For example, low-vigor cherry rootstocks are more sensitive under limiting soil conditions (Jiménez et al., 2007). Also, depending on the rootstock and the variety used, rootstocks with more TSCA have lower production efficiency (Zarrouk et al., 2005). This can be explained by 
the fact that vigorous vegetative growth competes with fruit growth and production (Caruso et al., 1997). The different hydraulic properties of a rootstock can define vegetative growth rates of trees. The vigor is explained by a mechanical effect of the hydraulic conductance, where the most vigorous rootstock remains in a condition of high water status in trees as compared to low vigor rootstocks, leading to the more dwarfing rootstocks with lower daily growth of stems and reduction in photosynthesis, as observed in grafted peach varieties (Solari et al., 2006a). Among other properties, rootstocks alter transport rates of auxin and cytokinins within the plant, having an hormonal effect as observed in Prunus rootstocks (Sorce et al., 2002). Finally, we must consider that rootstocks inducing different vigor can modify the expression of genes in both parts of the plant, the graft zone and the aerial part, altering the time when meristematic activity stops in vegetative buds, and modifying the expression of genes related to metabolism of brassinosteroids, flavonoids and cell wall synthesis in cherry (Prassinos et al., 2009).

The implementation of pedestrian orchards has been used in recent decades to improve production efficiency and reduce labor costs. For this reason the new generation of low-vigor inducing rootstocks in Prunus, which will adapt to suit modern orchards, is regarded as a key objective in a breeding program.

\section{Scion-rootstock graft incompatibility}

The limiting factor for the widespread use of some Prunus spp. for peach and cherry production is the lack of commercial rootstocks having a wide range of compatibility with various cultivars (Okie, 1987; Zarrouk et al., 2006). Scion/rootstock graft compatibility is a critical issue for orchard performance and longevity. It is perhaps more of a problem in cherry, almond, and especially apricot, than in peach or plum (Lang and Ophardt, 2000). In general, good compatibility occurs in cultivars and species closely related and some genera that have some degree of relatedness. In contrast, taxonomically distant species often manifest incompatibility (Rom and Carlson, 1987).

To remain physiologically healthy, rootstock and scion should be intimately unite, at least during the commercial life of the tree, providing a viable system for the uptake and translocation of minerals, water, assimilates, and hormones throughout the entire lifespan of the plant (Webster, 1995; Martínez-Ballesta et al., 2010). In this way, graft incompatibility leads to unhealthy trees, breakage at the graft union, premature dead or failure of the graft combination and incapacity to form a strong and lasting functional union (Zarrouk et al., 2006).

Previous studies described two types of incompatibility situations. The "translocated" graft incompatibility, which is usually expressed during the first year after grafting in the form of growth cessation, defoliation, and leaf discoloration (Herrero, 1951; Mosse, 1962). In peach/ plum combinations, this type of incompatibility has been associated with both biochemical and functional alterations at the graft interface, inducing a carbohydrate blockage in the scion above the graft union (Moing and Carde, 1988; Moing et al., 1990). Nevertheless, incompatibility symptoms may occur at later stage of development, knowing as "localized" incompatibility (Herrero, 1951; Mosse, 1962). In this case, the presence of some biochemical alterations across the graft union of Prunus may lead to a slight and delayed incompatibility as has been described in cherry and peach/plum combinations (Treutter and Feucht, 1991). This type of incompatibility is characterized by anatomical irregularities at the rootstock/scion union interface with breaks in vascular and cambial continuity patterns and poor vascular connections inducing mechanical weakness of the union (Errea et al., 2001), which may break after years of the orchard establishment, leading to the major economic losses (Herrero, 1951).

The physiological and metabolic mechanisms by which incompatibility is caused and expressed remain unclear (Zarrouk et al., 2006), and several hypotheses have been described. Improvements in the knowledge of metabolic compounds that control the incompatibility response and graft establishment in Prunus spp., could help the development of biochemical markers for their use in metabolite-directed rootstock breeding programs.

\section{Abiotic stresses}

Root asphyxia. Proper relationship between oxygen and water at the root zone is necessary for an accurate stone fruit tree development. Soils could induce root asphyxia to different rootstocks. While hypoxia often occurs in specific productive areas, it is possible to induce this stress with excessive irrigation or soil compaction (Holzapfel et al., 2009). One of the main targets in rootstock breeding in Prunus species is to get asphyxia tolerance or resistance. The hypoxic condition occurs when partial oxygen pressure decreases to a point at which the ATP production is limited in the mitochondria, whereas anoxia occurs when available oxygen decreases until ATP production, by oxidative phosphorylation, is negligible compared to ATP generated by glycolysis and fermentation (Drew, 1997; Dat et al., 2004). The condition of flooded soils, where the diffusion of gases in soil (including oxygen) falls drastically, is one of the most important factors in the evolution of plants and yields achieved by crops worldwide.

The exact mechanism by which plants sense early oxygen deficiency is unknown. In nature it is common that plants under a flooding condition is first subjected to an hypoxic condition where oxygen decreases gradually to reach the condition of anoxia, which gives time to the plants to generate defense responses before the environmental condition becomes lethal (Drew, 1997). Response of sensitive rootstocks to water logging, such 
as the peach-almond hybrids 'Felinem' and 'Garnem' exhibit increased activity of defense enzymes against oxidative damage as compared to tolerant Myrobalan plum rootstocks (Amador et al., 2012). They found that it was not possible to establish a direct relationship among the activity of the enzymes: peroxidase (POD), superoxide dismutase (SOD) and catalase (CAT), and tolerance to water logging conditions. These enzymes have been associated with preventive protection against oxidative damage that could occurs post-anoxia when roots are again under high oxygen conditions after water has drained from the soil (Drew, 1997; Igamberdiev et al., 2005).

Others responses in plants under flooding conditions have been linked to hormone-induced and ethylene signals (Dat et al., 2004). Apparently, there is a synthesis of 1-aminocyclopropane-1-carboxylic acid (ACC), a precursor of ethylene in roots under hypoxia, which once reaching the aerial part is converted to ethylene in the presence of oxygen by the action of ACC oxidase, thus regulating shoot growth in the aerial part and triggering responses such as epinasty (Jackson, 2002) or leaf senescence (Arbona and Gómez-Cadenas, 2008). Also, in the submerged part of the plant, ethylene is involved in the generation of hypertrophied lenticels in the stems (Larson et al., 1992), and in the formation of aerenchyma (Drew, 1997).

In a study with apricot (Prunus armeniaca L. 'Búlida'), Nicolás et al. (2005) showed that after removing plants from water logging conditions, these were not able to decrease the hydraulic resistance to the flow of sap until the emission of new roots. The roots generated under hypoxia in some species have been observed to be coated with lignin and suberin to avoid radial oxygen losses (Sauter, 2013; Yamauchi et al., 2013). Herrera et al. (2008) postulated that there is some similarity in the symptoms displayed by plants under water deficit stress and hypoxia. In this context, acclimatization phenomenon has been studied in different species of Prunus (Ranney, 1994). This author observed in 11 taxa that increasing the time of flooding decreased net photosynthesis. Similarly, in a study using eight taxa of Prunus, with ornamental cherry, water logging affected net photosynthesis (Jacobs and Johnson, 1996). Other studies also revealed the high sensitivity of net photosynthesis and stomatal conductance as first symptoms of water logging in several Prunus hosts: the rootstock selection GxN-9 (Prunus dulcis (Mill.) D.A. Webb $\times$ Prunus persica [L.] Batsch) (Martinazzo et al., 2011), apricot (P. armeniaca) (Domingo et al., 2002; Nicolás et al., 2005), peach (Insausti and Gorjón, 2013), in peach-almond interspecific crosses and Prunus cerasifera Ehrh. (Xiloyannis et al., 2002), and the peach-almond hybrids 'Felinem' and 'Garnem' rootstocks (Amador et al., 2012).

Subsequently, in Prunus, by prolonging the time of flooding many physiological anomalies can be observed or detected, the most common being lower chlorophyll content and less development (Amador et al., 2012; Insausti and Gorjón, 2013), increased defoliation (Ranney, 1994; Jacobs and Johnson, 1996), lower weight and root necrosis (Jacobs and Johnson, 1996), lower leaf water potential (Domingo et al., 2002; Nicolás et al., 2005; Insausti and Gorjón, 2013), less sap flow (Domingo et al., 2002; Nicolás et al., 2005), reduced turgor and leaf epinasty (Domingo et al., 2002), redness, and subsequent necrosis of leaf senescence and damage on vascular bundles (Iacona et al., 2013), all as symptoms of medium and long term appearance. In flooded peach (highly sensitive species) Insausti and Gorjón (2013) observed that fruit size was smaller and that harvested fruits produced ethylene earlier, advancing the climacteric ripening and softening of the fruit, seriously affecting fruit production. In most of these studies differences between sensitive and resistant plants of Prunus have been described in relation to the delay period to visualize first symptoms, degree of sensitivity, rate of recovery and survival of plants (Amador et al., 2012). Several of these indicators could be used in the selection of rootstocks for assessing tolerance to flooding conditions in Prunus.

The mechanisms of response to hypoxia and anoxia are still poorly investigated, especially in ligneous species such as Prunus. Most research in this species group are based on variables of growth, mainly morphological and physiological, but little has been done in reference to hormonal levels and even less at molecular level, focusing primarily on the activity of certain enzymes involved in the prevention of oxidative damage. So, it is necessary to validate the responses to hypoxia within Prunus species for their later use as indicators in breeding programs. This would allow implementing them as markers in early selection programs.

Salinity. Salinity problems often occur in arid and semiarid areas. The main ions causing problems are $\mathrm{Cl}^{-1}$, $\mathrm{SO}_{4}^{-2}, \mathrm{HCO}_{3}^{-1}, \mathrm{Na}^{+1}, \mathrm{Ca}^{+2}, \mathrm{Mg}^{+2}, \mathrm{NO}^{-3}$ and $\mathrm{K}^{+1}$, although in some areas B is also involved (Bernstein, 1975). Approximately $6 \%$ of world cultivated land has salinity problems where $\mathrm{NaCl}$ is usually the most abundant and soluble salt (Hasegawa et al., 2000; Munns and Tester, 2008). It is unclear how plants can first detect increases in salinity, as well as the signal transduction transmitted to the rest of the plant (Hasegawa et al., 2000).

The mechanisms of perception to salt stress and the signals transduction within the plant are not fully elucidated, and yet, compounded by the limited research conducted in this subject matter for woody species. In general, stone fruit crops tend to manifest a moderate to high sensitivity to salinity. Several interesting studies have been conducted in Prunus. In a trial with 'GF-677' and 'Mr.S. 2/5' rootstocks, grafted with peach and subjected to different $\mathrm{NaCl}(0$ 
to $120 \mathrm{mM}$ ) concentrations, an increased sensitivity in 'GF-677' in terms of growth and net assimilation of $\mathrm{CO}_{2}$ was observed (Massai et al., 2004). These authors also observed a reduced growth of the roots and increased accumulation of sorbitol in leaves. In almond, Ranjbarfordoei et al. (2006) showed that the content of chlorophyll and fluorescence parameters in leaves are adversely affected when the electrical conductivity of the irrigation water exceeded $3 \mathrm{dS} \mathrm{m}^{-1}$. Also working with almond clones under different levels of salinity $(0$ to $75 \mathrm{mM} \mathrm{NaCl}$ ), Najafian et al. (2008) found that with increased levels of stress, growth of stems, number of internodes, leaf area, fresh and dry weight of roots were reduced. Furthermore, in vitro cultured 'Gisela 6' cherry rootstock subjected to fluctuating saline concentrations evidenced an increase in the content of malondialdehyde and expression of SOD, ascorbate peroxidase, CAT, and glutathione reductase. El-Motaium et al. (1994) found that Myrobalan plum (Prunus cerasifera Ehrh.) is one of the most tolerant to salinity and B (less absorption of salts in the root), while 'Nemared' peach (Prunus persica (L.) Batsch) was one of the most sensitive (high salt content in the stem). By grafting these rootstocks with commercial varieties, the degree of tolerance of the rootstock is transferred to the variety.

In a 19-yr-old commercial Japanese plum (Prunus salicina Lindl. var. salicina) orchard grafted onto 'Marianna 2624' rootstock, different concentrations of a mixture of $\mathrm{NaCl}$ and $\mathrm{CaCl}_{2}$ from 0 to $28 \mathrm{mM}$ were applied (Ziska et al., 1991). These authors observed that much of $\mathrm{Na}^{+}$and $\mathrm{Cl}^{-}$was accumulated in woody tissues, while leaves mainly accumulated $\mathrm{Cl}^{-}$, causing lesions on leaves. They found that woody tissue is able to retain, apparently the movement of $\mathrm{Na}^{+}$to the leaves (which was not observed in young trees). In a second part of this study, these same authors observed that the most negative impact was caused by chlorides at leaf level, decreasing net photosynthesis, total carbohydrates, chlorophyll content, and leaf area (Ziska et al., 1990). In a 6-yr old plum trial, Catlin et al. (1993) observed that the recovery of trees following salt stress conditions may take several years, but ultimately achieved complete recovery. In this species, when salinity levels are higher $\left(8 \mathrm{dS} \mathrm{m}^{-1}\right.$ on irrigation water), production can be reduced by half, both in fruit number per tree and in fruit weight, evidencing severe leaf damage (Hoffman et al., 1989).

In the case of Prunus, evaluation to salt tolerance should be careful with the choice of type material used for experimentation; e.g. the use in vitro plants $v s$. year old plants or trees in commercial orchards, if plants used in trials are grafted or un-grafted rootstocks, and type of salt they are exposed to. All these variables may influence the final answer. It is important to determine what type of test gives the best response in a commercial orchard to improve detection of better sources of tolerance in the rootstock selection process.
Drought. Among the environmental factors that push the evolution of plants, water availability is the most important factor (Zhu, 2002), and within abiotic stresses, drought has the most alarming impact on agriculture (Reddy et al., 2004). Water stress is generated not only by the shortage of water in soil, but also by a high vapor pressure deficit (VPD), which closes stomata even though the soil is well moisten due to an increase in transpiration rates. Both phenomena, shortage of water and high VPD, occur simultaneously in arid and semiarid climates (Reddy et al., 2004; Chaves et al., 2009).

It is not known how the lack of water is perceived at the molecular or biochemical level (Reddy et al., 2004). The information at the molecular level in woody species is more limited. Working under water stress conditions, rootstocks 'Cadaman', 'GF-677', 'ROOTPAC 20' (P. besseyi $\times P$. cerasifera) and 'ROOTPAC R' ( $P$. cerasifera $\times P$. dulcis) grafted with 'Catherina' peach, increased the production of proline in roots and leaves, sorbitol in leaves and raffinose in roots, related to an increase in water use efficiency. A high expression of P5SC gene on 'GF-677' (tolerant) were associated with the high content of proline (Jiménez et al., 2013).

Several studies have observed the effects at stomatal level and photosynthesis in Prunus under drought. The values of midday water potential is related to stem growth, stomatal conductance, assimilation, and transpiration (Solari et al., 2006b). Interspecific Prunus hybrids under drought conditions decreases water potential, photosynthesis and transpiration, and significantly increase the activity of enzymes with antioxidant activity, which returns to normal values when plants are watered, while levels of ascorbate, glutathione and $\mathrm{H}_{2} \mathrm{O}_{2}$ increase during water deficit (Sofo et al., 2005).

At the production level, moderate deficits in specific phenological stages that do not affect production have been evaluated. In a study conducted in a commercial peach orchard grafted onto 'GF-677', Gelly et al. (2004) found that performing a controlled water deficit in phase II of fruit growth (growth stops during the hardening of fruit pit) improves fruit quality increasing the amount of soluble solids and enhancing color. Carry water deficit at this stage of fruit growth allows saving water without affecting fruit size. In another study carried out with almond variety 'Nonpareil' grafted on 'Nemaguard' peach, Esparza et al. (2001) observed a decreased performance after $2 \mathrm{yr}$ of water stress applied during floral initiation, mainly explained by a decrease in the renewal of fruitwood, without affecting the weight of seeds by the deficit of last season. Varying productive responses to water deficit is also related with the rootstock used, in terms of firmness of fruit, soluble solids content, and anthocyanin content. These variables can increase or decrease independently, improving or deteriorating various parameters of quality within a rootstock-scion combination, as has been observed in various combinations in peach (Besset et al., 2001). 
A drought tolerant rootstock will not necessarily be successful if the scion is a sensitive variety. The current worldwide situation strongly advises to conduct a major effort into selecting drought tolerant rootstocks adapted to future climate change. Finally, the importance of evaluating grafted plants should be taken into account, where the interaction occurs between the two components, rootstock and scion, in order to determine the real level of tolerance.

Iron chlorosis. Iron chlorosis problems often occurs in calcareous soils (Abadía et al., 2011). In most soils there is Fe abundance but not available to plants, being highly insoluble in the presence of oxygen and much less soluble in the presence of carbonates (Schmidt, 2003). It is unclear the mechanism by which plants detect the lack of $\mathrm{Fe}$. There are two main strategies to absorb $\mathrm{Fe}$ in the roots. Strategy I is mainly based on the activity of Fe-reductase enzyme belonging to the group ferric reductase oxidase (FRO) for the Prunus group, which reduces $\mathrm{Fe}^{+3}$ to $\mathrm{Fe}^{+2}$, and then is absorbed by the specific transporter, while Strategy II is exclusive to grass (Abadía et al., 2011).

The use of tolerant rootstocks to iron chlorosis is the best way to overcome this problem (Cellini et al., 2011). Jiménez et al. (2008) working with several Prunus rootstocks reported that Fe-reductase activity was affected by $\mathrm{Fe}$ availability in an hydroponic solution in which rootstocks known as resistant genotypes such as 'Adesoto' ( $P$. insititia L.), 'Felinem' (P.dulcis $\times$ P.persica) or 'GF 677' ( $P$.dulcis $\times$ P. persica), had increased activity of this enzyme as compared to the sensitive rootstocks 'Barrier' ( $P$. persica $\times$ P. davidiana (Carrière) N.E. Br.) and 'Cadaman' $(P$. persica $\times P$. davidiana $)$. They also found that rootstocks with higher SPAD values correlate well with increased tolerance to Fe chlorosis. Similarly, Cinelli et al. (1995) observed that resistant rootstocks are better suited to reduce $\mathrm{Fe}$ under stress, as compared to the sensitive 'Nemaguard' peach. Visible symptoms manifested mainly in new leaves and SPAD values fell faster in young leaves than older leaves. In another study with 'Nemaguard' established in a Fe deficient medium, Bohórquez et al. (2001) observed that $\mathrm{Fe}$ activity reduction of roots does not increase unless there is $\mathrm{Fe}$ or another metal such as $\mathrm{Zn}$ in the rhizosphere. In other study using potassium bicarbonate solutions to simulate the effects of a calcareous soil, with a $\mathrm{pH}$ increase of 8.5 , almonds showed a tolerant response, while peaches exhibited a variable response according to genotype, being 'Nemaguard' sensitive (Shi and Byrne, 1995). The root level response in tolerant rootstocks, such as 'Adesoto' reached the highest contents of organic compounds and amino acids (Jiménez et al., 2011).

Comparing rootstocks with contrasting response to $\mathrm{Fe}$ chlorosis, such as 'GF 677', with 'Mr.S 2/5' and 'Ishtara' $[(P$. cerasifera $\times$ P. salicina $) \times(P$. cerasifera $\times P$. persica $)]$, Cellini et al. (2011) observed that tolerant rootstock has a higher content of glutathione and ascorbate, and additionally more glutathione reductase activity and NO content, with the highest antioxidant defense and less oxidative stress in the tolerant rootstock.

In commercial peach orchards growing on calcareous soils, Fe chlorosis deteriorates various physiological parameters, such as photosynthetic efficiency, assimilation, transpiration, and stomatal conductance (Eichert et al., 2010). Iron chlorosis decreased yield and fruit quality (Pestana et al., 2003). Visible symptoms of chlorosis rapidly appear followed by a decrease in performance with lesser fruit load and fruit size (ÁlvarezFernández et al., 2011).

Iron chlorosis is one of the most limiting factors in the production of Prunus and is determined by soil conditions that alter not only $\mathrm{Fe}$ availability, but also $\mathrm{Fe}$ uptake and transport within the plant. At the molecular and metabolic levels, several questions on perception and signal transduction, as well as its internal transport remain unanswered. The new generation of resistant rootstocks is one of the most effective ways to address this problem in stone fruit species and is, therefore, necessary to design tests that are effective in selecting tolerant rootstocks.

\section{Biotic stress}

Root-knot nematode resistance. One of the major pests in stone fruit orchards worldwide are plant parasitic nematodes (PPN) (Nyczepir and Esmenjaud, 2008). PPN are generally microscopic, colorless and un-segmented eel-shaped organisms. They are considered important crop pests but due to their small size and because they live in the soil, they are difficult to detect, identify and control (De Ley et al., 2005; Powers, 2004). Fruit tree crops like almond ( $P$. amygdalus Batsch), cherry $(P$. avium (L.) L., and P. cerasus L.), peach (P. persica) and plum ( $P$. cerasifera, $P$. domestica $\mathrm{L}$., and $P$. salicina.), are susceptible to PPN attack worldwide (Nyczepir, 1991; Esmenjaud et al., 1996; 1997; Stalin et al., 1998; Pinochet, 2000; Rosso et al., 2004; Di Vito et al., 2005; Walters et al., 2008; Nyczepir and Thomas, 2009; Ye et al., 2009; Bosselut et al., 2011). The effects of PPN in crops are often underestimated but in general, it is accepted that on average, nematodes are annually reducing the global agricultural production by about $10 \%$ to $12 \%$ (Agrios, 2005).

The four major PPN associated with severe losses in stone fruits orchards worldwide are: root-knot (Meloidogyne spp.), ring (Mesocriconema spp.), rootlesion (Pratylenchus spp.), and dagger (Xiphinema spp.) nematodes. Root-knot nematodes (RKN) are considered by far the most damaging nematodes in the world and reduce fruit production in several economically important Prunus species (Nyczepir and Esmenjaud, 2008). The host response of Prunus rootstocks to RKN species and populations has been studied for many decades in USA and Europe. 
Traditionally, PPN control has been based mainly on chemical compounds (nematicides). However, the negative impact on environment and ineffectiveness after prolonged use have led to a total ban or restricted use of most chemical nematicides, especially soil fumigants, and an urgent need for safe and more effective alternatives (Esmenjaud et al., 1997; Perry et al., 2009; Radwan et al., 2012). The most economic and environmentally sound method for managing RKN in Prunus spp. crops is the use of resistant rootstocks (Fernández et al., 1994; Esmenjaud et al., 1997; Pinochet, 1997; Pinochet et al., 1999; Nyczepir and Esmenjaud, 2008; Perry et al., 2009; Verdejo-Lucas and Talavera, 2009; Khallouk et al., 2011; Pofu et al., 2012).

Resistance is used to describe the ability of plants to suppress nematode development and/or reproduction. It can range from low to moderate (partial or intermediate) resistance to high resistance. A completely or highly resistant plant allows no nematode reproduction or only very minor reproduction. Partially or moderately resistant plants allow a low reproduction. In contrast, susceptibility allows normal nematode development, enhancing the expression of any associated disease (Roberts, 2002). Studies focused in mechanisms of resistance to RKN have described diverse plant responses to nematode attacks, ranging from strong early hypersensitive-like reaction leading to rapid juvenile death to late inhibition in the formation of giant cells associated with an incomplete development of the nematode reproductive cycle (Marull et al., 1994; Khallouk et al., 2011).

Starr and Mercer (2009) summarize the key steps for identifying and evaluating crop resistance to RKN. First, it is necessary to identify RKN species present in the area of interest, and then evaluate the plant suitability (host-response) to RKN species and isolated populations. Therefore, the host response of Prunus rootstocks must be evaluated specially against populations with differences in virulence of a particular species or a mixture of virulent populations involving several RKN species, to ensure a broad spectrum of resistance (Esmenjaud et al., 1994; Pinochet et al., 1999; Pinochet, 2009). Thus, the detected source resistance can be identified and incorporated in a resistance breeding program. Prunus rootstocks with broad resistance to RKN have been found in the subgenus Amygdalus among wild peach (P. davidiana) or cultivated peaches $(P$. persica) or almond $(P$. dulcis) or peachalmond hybrid rootstocks (Esmenjaud et al., 1994; 1997; Pinochet, 1997; Nyczepir and Esmenjaud, 2008; Bosellut et al., 2011). Broad resistance has also been found in the subgenus Prunophora (P. cerasifera, P. insititia, $P$. domestica). In the plum group, high level of resistance to RKN has been found in 'Marianna' $(P$. cerasifera $\times$ $P$. munsoniana W. Wight \& Hedrick) and Myrobalan ( $P$. cerasifera) (Esmenjaud et al., 1994; 1997). The so called $M a$ genes of resistance in some Myrobalan clones suppress nematode reproduction and confer a complete spectrum, high level and stable resistance to Meloidogyne arenaria (Neal, 1889), M. incognita (Kofoid \& White, 1919), $M$. javanica (Treub, 1885), and M. floridensis (Nyczepir and Thomas, 2009).

Research conducted for developing nematode resistant crops worldwide have made major contributions to nematode management. Important economic profit has been achieved in the case of tomato, peach, grape, tobacco, and others major crops. The creation of nematode resistant crops leads to lower nematode population densities, with obvious long-term benefits in an agricultural system (Roberts, 2002; Starr and Mercer, 2009). New inputs through molecular biology, such as marker assisted selection (MAS) can aid plant breeders with new tools for accelerating the breeding process for incorporating nematode resistance (Esmenjaud et al., 1997).

Disease resistance. Breeding programs oriented towards developing new Prunus rootstocks require the use of germplasm resistant or tolerant to soil-borne fungal pathogens and orchard replant problems. Resistant rootstocks, and to a lesser degree tolerant rootstocks, provide an agronomic solution to Prunus fruit growers allowing an increase in productivity and improved efficiency via better tree survival in soils infested with pathogens like fungi, bacteria, virus, and virus-like diseases.

In poorly drained and dense clayish soils, Prunus rootstock are at risk of being infected with crown gall (Agrobacterium tumefaciens), crown rot (Phytophthora spp.), bacterial canker (P. syringae pv. syringae), oak root rot fungus, Armillaria mellea and Armillaria tabescens. Both fungi and bacteria are difficult to control or eradicate; therefore, incorporation of genetic resistance into rootstocks is a highly desirable option (Reighard and Loreti, 2008). However, this challenge has proven to be a difficult task for some pathogens since it first requires identifying sources of resistance, and second to transfer these sources into commercial material. For example, resistant genes against crown gall and oak root rot have been detected in a few wild sources but the trait has been difficult, if not impossible, to transfer into commercial or experimental Prunus (Pinochet et al., 2002). Furthermore, the difficulty in working with soil borne fungi and bacteria is the pathogenic diversity of these organisms.

Replant problems in stone fruit crop are of major concern and thus require a special mention. Replant disease is a syndrome expressed as a failure in tree establishment, suppressed growth, and shortened productive life. One of the most common practices in fruit tree cultivation worldwide is repeated cropping. Soil-borne pathogens (nematodes, fungi, and bacteria), are essential components associated with replant disease. Other abiotic stress factors are also involved. However, it is difficult to determine the primary causal agent or the predominating factor for each replant situation. In most cases, the existence of a combination of factors whose damaging effects over the 
plant are accumulative is accepted. Thus, choosing a rootstock that would have multiple resistance or tolerance to several of these damage causing factors is a priority to assure success during the establishment of the tree, and afterwards, during its productive life (Calvet et al., 2000).

\section{Use of molecular markers}

Molecular markers are based in the identification of inheritable DNA sequence differences (polymorphisms). This is a procedure that combines both traditional breeding strategies and molecular tools for selecting plant material with traits of interest, such as color, size, or biotic/abiotic stress resistance. A molecular marker may be a short DNA sequence, such as a single base-pair change (single nucleotide polymorphism, SNP), or a long one, like minisatellites, which are usually defined as the repetition in tandem of a short (6 to $100 \mathrm{bp}$ ) motif spanning $0.5 \mathrm{~kb}$ to several kilobases (Vergnaud and Denoeud, 2000). Other important kind of molecular markers are microsatellites or Simple Sequence Repeats (SSRs), which are sequences of 1 to $6 \mathrm{bp}$ repeated in tandem that are frequently found in the genomes of prokaryotes and eukaryotes (Zane et al., 2002; Kalia et al., 2011). The increased genomic resources available from the last years, such as whole genome sequences and high-density genotyping platforms, are revealing important structural and regulatory genes, as well as molecular polymorphisms associated with important agronomic traits (Verde et al., 2012; Dirlewanger et al., 2012).

The identification of regions that contribute to the phenotypic variance of a character permits the selection of genotypes carrying these loci, which are not affected by interaction with the environment. Using the methodologies that identify genomic regions involved in the expression of other traits mainly developed for peach and cherry to a lesser extent, it would be possible to identify the genetic determinants involved in detecting tolerance for hypoxia in Prunus rootstocks. A review on this topic is presented in the article by Guajardo et al. included in this special issue.

\section{CONCLUSIONS}

Current fruit production requires a rootstock incorporating traits like low vigor, compatibility with a wide number of varieties, and resistance or tolerance to biotic (diseases and nematodes) and abiotic (hypoxia, water stress, salinity and $\mathrm{Fe}$ chlorosis) stresses, which conforms a complex ideotype and a great challenge for the breeder. For this it is important to seek new sources of variation within the genus Prunus spp. by interspecific crosses. This requires have a broad collection of materials that will open new alternatives to the breeder to break the barriers of resistance and/or tolerance to pests and diseases. In this sense a quick way of access to new species is the implementation of a collection of cryopreserved pollen, which offers the possibility to incorporate large number genotypes without the wait entry into the reproductive stage.

Moreover, the evaluation of progenies require understand physiological and molecular mechanisms behind the responses to biotic and abiotic stresses. Therefore it is important that rootstock breeding program has a multidisciplinary team of scientists supporting in the areas of genomics, physiology, and agronomy. The generation of basic knowledge of each area should be integrated to develop appropriate screening tests and early selection tools to shorten the evaluation time for each trait. At this point genomics can be helpful, both the possibility of using molecular markers and genetic characterization of the parent, which will guide the planning of crosses. This support will allow the agronomic evaluation of genotypes in the field in less time.

Finally the productive evaluation of genotypes requires several seasons of observation and different environments to obtain a variety adapted to different conditions of soil and climate. The implementation of a network of evaluation sites enables more information of performance of each material in every season, which added to the specific tests generates a detailed characterization of each genotype, facilitating the choice of the most appropriate rootstock for the conditions of each producer.

\section{ACKNOWLEDGEMENTS}

We thank the Centro de Estudios Avanzados en Fruticultura (CEAF) and the CONICYT Regional project R08I1001 for financing this review.

\section{LITERATURE CITED}

Abadía, J., S. Vázquez, R. Rellán-Álvarez, H. El-Jendoubi, A. Abadía, A. Álvarez-Fernández, et al. 2011. Towards a knowledgebased correction of iron chlorosis. Plant Physiology and Biochemistry 49:471-482.

Agrios, G. 2005. Plant pathology. $5^{\text {th }}$ ed. Elsevier Academic Press, Amsterdam, The Netherlands.

Álvarez-Fernández, A., J.C. Melgar, J. Abadía, and A. Abadía. 2011. Effects of moderate and severe iron deficiency chlorosis on fruit yield, appearance and composition in pear (Pyrus communis L.) and peach (Prunus persica (L.) Batsch). Environmental and Experimental Botany 71:280-286.

Amador, M.L., S. Sancho, B. Bielsa, J. Gomez-Aparisi, and M.J. Rubio-Cabetas. 2012. Physiological and biochemical parameters controlling waterlogging stress tolerance in Prunus before and after drainage. Physiologia Plantarum 144:357-368.

Andrews, P.K., and C. Serrano. 1993. Graft incompatibility. J. Janick (ed.) Horticultural Reviews 15. John Wiley \& Sons, Oxford, UK. doi:10.1002/9780470650547.ch5.

Arbona, V., and A. Gómez-Cadenas. 2008. Hormonal modulation of citrus responses to flooding. Journal of Plant Growth Regulation 27:241-250.

Bernstein, L. 1975. Effects of salinity and sodicity on plant growth. Annual Review of Phytopathology 13:295-312.

Besset, J., M. Génard, T. Girard, V. Serra, and C. Bussi. 2001. Effect of water stress applied during the final stage of rapid growth on peach trees (cv. Big-Top). Scientia Horticulturae 91:289-303. 
Bohórquez, J.M., F.J. Romera, and E. Alcántara. 2001. Effect of $\mathrm{Fe}^{3+}, \mathrm{Zn}^{2+}$ and $\mathrm{Mn}^{2+}$ on ferric reducing capacity and regreening process of the peach rootstock Nemaguard (Prunus persica (L.) Batsch). Plant and Soil 237:157-163.

Bosselut, N., C. Van Ghelder, M. Claverie, R. Voisin, J. Onesto, M. Rosso, et al. 2011. Agrobacterium rhizogenes-mediated transformation of Prunus as an alternative for gene functional analysis in hairy-roots and composite plants. Plant Cell Reports. doi:10.1007/s00299-011-1043-9.

Calvet, C., V. Estaún, A. Camprubí, y J. Pinochet. 2000. Enfermedades de replantación en los frutales. p. 107-109. In E. Montesinos, P. Melgarejo, M.A. Cambra, and J. Pinochet (eds.) Enfermedades de los frutales de pepita y hueso. Monografía de la Sociedad Española de Fitopatología N 3.147 p. Ediciones Mundi-Prensa, Madrid, España.

Caruso, T., P. Inglese, M. Sidari, and F. Sottile. 1997. Rootstock influences seasonal dry matter and carbohydrate content and partitioning in above-ground components of 'Flordaprince' peach trees. Journal of the American Society for Horticultural Science 122:673-679.

Catlin, P., G. Hoffman, R. Mead, and R. Johnson. 1993. Long-term response of mature plum trees to salinity. Irrigation Science 13:171-176.

Cellini, A., F.J. Corpas, J.B. Barroso, and A. Masia. 2011. Nitric oxide content is associated with tolerance to bicarbonate-induced chlorosis in micropropagated Prunus explants. Journal of Plant Physiology 168:1543-1549.

Chaves, M.M., J. Flexas, and C. Pinheiro. 2009. Photosynthesis under drought and salt stress: Regulation mechanisms from whole plant to cell. Annals of Botany 103:551-560.

Cinelli, F., R. Viti, D.H. Byrne, and D.W. Reed. 1995. Physiological characterization of two peach seedling rootstocks in bicarbonate nutrient solution. p. 323-328. In J. Abadía (ed.) Iron nutrition in soils and plants. Vol. 59. Springer-Science+Bussines Media, Dordrecht, The Netherlands.

Cummins, J.N., and H.S. Aldwinckle. 1995. Breeding rootstocks for tree fruit crops. New Zealand Journal of Crop and Horticultural Science 23:395-402.

Dat, J.F., N. Capelli, H. Folzer, P. Bourgeade, and P-M. Badot. 2004. Sensing and signalling during plant flooding. Plant Physiology and Biochemistry 42:273-282.

De Ley, P., I. Tandingan, K. Morris, E. Abebe, M. MundoOcampo, M. Poder, et al. 2005. An integrated approach to fast and informative morphological vouchering of nematodes for applications in molecular barcoding. Philosophical Transactions of the Royal Society Biological Sciences 360:1945-1958.

Di Vito, M., A. Simeone, and F. Catalano. 2005. Effect of the rootknot nematode, Meloidogyne javanica, on the growth of a peach (Prunus persica) rootstock in pots. Nematologia Mediterranea 33:87-90.

Dirlewanger, E., J. Quero-García, L. Le Dantec, P. Lambert, D. Ruiz, L. Dondini, et al. 2012. Comparison of the genetic determinism of two key phenological traits, flowering and maturity dates, in three Prunus species: peach, apricot and sweet cherry. Heredity 109:280-292.

Domingo, R., A. Pérez-Pastor, and M.C. Ruiz-Sánchez. 2002. Physiological responses of apricot plants grafted on two different rootstocks to flooding conditions. Journal of Plant Physiology 159:725-732

Drew, M.C. 1997. Oxygen deficiency and root metabolism: Injury and acclimation under hypoxia and anoxia. Annual Review of Plant Physiology and Plant Molecular Biology 48:223-250.

Eichert, T., J.J. Peguero-Pina, E. Gil-Pelegrín, A. Heredia, and V. Fernández. 2010. Effects of iron chlorosis and iron resupply on leaf xylem architecture, water relations, gas exchange and stomatal performance of field-grown peach (Prunus persica). Physiologia Plantarum 138:48-59.

El-Motaium, R., H. Hu, and P.H. Brown. 1994. The relative tolerance of six Prunus rootstocks to boron and salinity. Journal of the American Society for Horticultural Science 119:1169-1175.
Errea, P., L. Garay, and J.A. Marín. 2001. Early detection of graft incompatibility in apricot (Prunus armeniaca) using in vitro techniques. Physiologia Plantarum 112:135-141.

Esmenjaud, D., J. Minot, and R. Voisin. 1996. Effects of durable inoculums pressure and high temperature on root galling, nematode numbers and survival of Myrobalan plum genotypes (Prunus cerasifera Ehr.) highly resistant to Meloidogyne spp. Fundamental and Applied Nematology 19:85-90.

Esmenjaud, D., J. Minot, R. Voisin, J. Pinochet, M. Simard, and G. Salesses. 1994. Inter- and intraspecific variability in Myrobalan plum, peach, and peach-almond rootstock using 22 root-knot nematode populations. Journal of the American Society for Horticultural Science 119:94-100.

Esmenjaud, D., J. Minot, R. Voisin, J. Pinochet, M. Simard, and G. Salesses. 1997. Differential response to root-knot nematodes in Prunus species and correlative genetic implications. Journal of Nematology 29:370-380.

Esparza, G., T. DeJong, S. Weinbaum, and I. Klein. 2001 Effects of irrigation deprivation during the harvest period on yield determinants in mature almond trees. Tree Physiology 21:1073-1079.

Fernández, C., J. Pinochet, D. Esmenjaud, G. Salesses, and A. Felipe 1994. Resistance among new Prunus rootstocks and selections to root-knot nematodes from Spain and France. American Society for Horticultural Science 29:1064-1067.

Gelly, M., I. Recasens, J. Girona, M. Mata, A. Arbones, J. Rufat, et al. 2004. Effects of stage II and postharvest deficit irrigation on peach quality during maturation and after cold storage. Journal of the Science of Food and Agriculture 84:561-568.

Hasegawa, P.M., R.A. Bressan, J-K. Zhu, and H.J. Bohnert 2000. Plant cellular and molecular responses to high salinity. Annual Review of Plant Physiology and Plant Molecular Biology 51:463-499.

Herrera, A., W. Tezara, O. Marín, and E. Rengifo. 2008. Stomatal and non-stomatal limitations of photosynthesis in trees of a tropical seasonally flooded forest. Physiologia Plantarum 134:41-48.

Herrero, J. 1951. Studies of compatible and incompatible graft combinations with special reference to hardy fruit trees. Journal of Horticultural Science 26:186-237.

Hartmann, H.T., D.E. Kester, F.T. Davies Jr., and R.L. Geneve. 2002. Plant propagation principle and practices. $7^{\text {th }}$ ed. 880 p. Prentice Hall, Upper Saddle River, New Jersey, USA.

Hoffman, G., P. Catlin, R. Mead, R. Johnson, L. Francois, and D. Goldhamer. 1989. Yield and foliar injury responses of mature plum trees to salinity. Irrigation Science 10:215-229.

Holzapfel, E., A. Pannuncio, I. Lorite, A. Silva de Oliveira, and I. Farkas. 2009. Design and management of irrigation systems. Chilean Journal of Agricultural Research 69: 17-25.

Iacona, C., M. Cirilli, A. Zega, E. Frioni, C. Silvestri, and R. Muleo. 2013. A somaclonal myrobalan rootstock increases waterlogging tolerance to peach cultivar in controlled conditions. Scientia Horticulturae 156:1-8

Igamberdiev, A.U., K. Baron, N. Manac'h-Little, M. Stoimenova, and R.D. Hill. 2005. The haemoglobin/nitric oxide cycle: Involvement in flooding stress and effects on hormone signalling. Annals of Botany 96:557-564.

Insausti, P., and S. Gorjón. 2013. Floods affect physiological and growth variables of peach trees (Prunus persica (L.) Batsch), as well as the postharvest behavior of fruits. Scientia Horticulturae $152: 56-60$

Jackson, M.B. 2002. Long-distance signalling from roots to shoots assessed: The flooding story. Journal of Experimental Botany 53:175-181.

Jacobs, K., and G. Johnson. 1996. Ornamental cherry tolerance of flooding and Phytophthora root rot. American Society for Horticultural Science 31:988-991.

Jiménez, S., J. Dridi, D. Gutiérrez, D. Moret, J.J. Irigoyen, M.A. Moreno, et al. 2013. Physiological, biochemical and molecular responses in four Prunus rootstocks submitted to drought stress. Tree Physiology 33:1061-1075. 
Jiménez, S., N. Ollat, C. Deborde, M. Maucourt, R. Rellán-Álvarez, M.A. Moreno, et al. 2011. Metabolic response in roots of Prunus rootstocks submitted to iron chlorosis. Journal of Plant Physiology 168:415-423

Jiménez, S., J. Pinochet, A. Abadía, M.A. Moreno, and Y. Gogorcena. 2008. Tolerance response to iron chlorosis of Prunus selections as rootstocks. American Society for Horticultural Science 43:304-309.

Jiménez, S., J. Pinochet, Y. Gogorcena, J.A. Betrán, and M.A. Moreno. 2007. Influence of different vigour cherry rootstocks on leaves and shoots mineral composition. Scientia Horticulturae 112:73-79.

Kalia, R., M. Rai, S. Kalia, R, Singh, and A. Dhawan. 2011. Microsatellite markers: An overview of the recent progress in plants. Euphytica 177:309-334.

Khallouk, S., R. Voisin, C. Van Ghelder, G. Engler, S. Amiri, and D. Esmenjaud. 2011. Histological mechanisms of the resistance conferred by the $M a$ Gene against Meloidogyne incognita on Prunus spp. Phytopathology 101:945-951.

Kubota, Ch., M.A. McClure, N. Kokalis-Burelle, M.G. Bausher, and E.N. Rosskopf. 2008. Vegetable grafting: History, use, and current technology status in North America. American Society for Horticultural Science 43:1664-1669.

Lang, G.A., and D. Ophardt. 2000. Intensive crop regulation strategies in sweet cherries. Acta Horticulturae 514:227-234.

Larson, K.D., B. Schaffer, and F.S. Davies. 1992. Floodwater oxygen content, ethylene production and lenticel hypertrophy in flooded mango trees. American Society for Horticultural Science 27:595-595.

Layne, R.E. 1994. Prunus rootstock affect long-term orchard performance of 'Redhaven' peach on Brookston clay loam. American Society for Horticultural Science 29:167-171.

Martinazzo, E.G., A.T. Perboni, M.E. Farias, V.J. Bianchi, and M.A. Bacarin. 2011. Photosynthetic activity in the rootstock of hybrid peach trees submitted to water restriction and flooding. Brazilian Journal of Plant Physiology 23:231-236.

Martínez-Ballesta, M.C., C. Alcaraz-López, B. Muries, C. MotaCadenas, and M. Carvajal. 2010. Physiological aspects of rootstock-scion interactions. Scientia Horticulturae 127:112-118.

Marull, J., J. Pinochet, A. Felipe, and J. Cenis. 1994. Resistance verification in Prunus selections to a mixture of 13 Meloidogyne isolates and resistance mechanisms of a peach-almond hybrid to M. javanica. Fundamental and Applied Nematology 16:85-92.

Massai, R., D. Remorini, and M. Tattini. 2004. Gas exchange, water relations and osmotic adjustment in two scion/rootstock combinations of Prunus under various salinity concentrations. Plant and Soil 259:153-162.

Mink, G.I. 1993. Pollen and seed-transmitted viruses and viroids. Annual Review of Phytopathology 31:375-402.

Moing, A., F. Carbonne, and J.P. Gaudillère. 1990. Growth and carbon partitioning in compatible and incompatible peach/plum grafts. Physiologia Plantarum 79:540-546.

Moing, A., and J.P. Carde. 1988. Growth, cambial activity and phloem structure in compatible and incompatible peach/plum grafts. Tree Physiology 4:347-359.

Mosse, B. 1962. Graft-incompatibility in fruit trees. p. 28-36. Commonwealth Bureau of Horticulture and Plantation Crops, East Malling, Kent, UK.

Munns, R., and M. Tester. 2008. Mechanisms of salinity tolerance. Annual Review of Plant Biology 59:651-681.

Najafian, S., M. Rahemi, and V. Tavallali. 2008. Effect of salinity on tolerance of two bitter almond rootstocks. American-Eurasian Journal of Agricultural and Environmental Sciences 3:264-268.

Nicolás, E., A. Torrecillas, J. Dell'Amico, and J.J. Alarcón. 2005. The effect of short-term flooding on the sap flow, gas exchange and hydraulic conductivity of young apricot trees. Trees 19:51-57.

Nyczepir, A. 1991. Nematode management strategies in stone fruits in the United States. Journal of Nematology 23:334-341.

Nyczepir, A., and D. Esmenjaud. 2008. Nematodes. p. 505-535 In Layne, D., and Bassi, D. (eds.) The peach: Botany, production and uses. CABI publishing, Wallingford, Oxon, UK.
Nyczepir, A., and S. Thomas. 2009. Current and future management strategies in intensive crop production systems. p. 412-443. In Perry, R., M. Moens, and J. Starr (eds.) Root-knot nematodes. CABI Publishing, Wallingford, Oxon, UK.

Okie, W.R. 1987. Plum rootstocks. p. 321-360. In R.F. Carlson (ed.) Rootstocks for fruit crops. Wiley, New York, USA.

Perry, R.L. 1987. Cherry rootstocks. p. 217-264. In Rom, R.C., and R.F. Carlson (eds.) Rootstocks for fruit crops. John Wiley and Sons, New York, USA.

Perry, R., M. Moens, and J. Starr. 2009. Meloidogyne species a diverse group of novel and important plant parasites. p. 1-17. In Perry, R., M. Moens, and J. Starr (eds.) Root-knot nematodes. CABI Publishing, Wallingford, Oxon, UK.

Pestana, M., A. de Varennes, and E.A. Faria. 2003. Diagnosis and correction of iron chlorosis in fruit trees: a review. Journal of Food Agriculture and Environment 1:46-51.

Pinochet, J. 1997. Breeding and selection for resistance to rootknot and lesion nematodes in Prunus rootstocks adapted to Mediterranean conditions. Phytoparasitica 25:271-274.

Pinochet, J. 2000. Enfermedades causadas por nematodos. Parte V. p. 97-103. In Montesinos, E., P. Melgarejo, M.A. Cambra, y J. Pinochet (eds.) Enfermedades de los frutales de pepita y hueso. Monografía de la Sociedad Española de Fitopatología No 3.147 p. Mundi-Prensa, Madrid, España.

Pinochet, J. 2009. 'Greenpac', a new peach hybrid rootstock adapted to Mediterranean conditions. American Society for Horticultural Science 44:1456-1470.

Pinochet, J., C. Calvet, A. Hernández-Dorrego, A. Bonet, A. Felipe, and M. Moreno. 1999. Resistance of peach and plum rootstock from Spain, France and Italy to root-knot nematode Meloidogyne javanica. American Society for Horticultural Science 34:1259-1262.

Pinochet, J., C. Fernández, M. Cunill, J. Torrents, A. Felipe, M.M. López, et al. 2002. Response of new interspecific hybrids for peach to root-knot and lesion nematodes, and crown gall. Acta Horticulturae 592:707-716

Pofu, K., P. Mashela, and H. Shimelis. 2012. Inter-generic grafting in watermelon for managing Meloidogyne species: A Review. Scientific Research and Essays 7:107-113.

Powers, T. 2004. Nematode molecular diagnostics: From bands to barcodes. Annual Review of Phytopathology 42:367-383.

Prassinos, C., J-H. Ko, G. Lang, A.F. Iezzoni, and K-H. Han. 2009. Rootstock-induced dwarfing in cherries is caused by differential cessation of terminal meristem growth and is triggered by rootstock-specific gene regulation. Tree Physiology 29:927-936.

Radwan, M., S. Farrag, M. Abu-Elamayem, and N. Ahmed. 2012. Biological control of the root-knot nematode, Meloidogyne incognita on tomato using bioproducts of microbial origin. Applied Soil Ecology 56:58-62.

Ranjbarfordoei, A., R. Samson, and P. Damme. 2006. Chlorophyll fluorescence performance of sweet almond [Prunus dulcis (Miller) D. Webb] in response to salinity stress induced by $\mathrm{NaCl}$. Photosynthetica 44:513-522.

Ranney, T.G. 1994. Differential tolerance of eleven Prunus taxa to root zone flooding. Journal of Environmental Horticulture 12:138-138.

Reddy, A.R., K.V. Chaitanya, and M. Vivekanandan. 2004. Droughtinduced responses of photosynthesis and antioxidant metabolism in higher plants. Journal of Plant Physiology 161:1189-1202.

Reighard, G., and F. Loreti. 2008. Rootstock development. p. 193-220. In Layne, D., and D. Bassi (eds.) The peach: Botany, production and uses. CABI Publishing, Wallingford, Oxon, UK.

Roberts, P. 2002. Concepts and consequences of resistance. p. 2341. In Starr, J., R. Cook, and J. Bridge (eds.) Plant resistance to parasitic nematodes. CABI Publishing, Wallingford, Oxon, UK.

Rom, R.C., and R.F Carlson. 1987. Rootstocks for fruit crops. Wiley, New York, USA.

Rosso, L., A. De Candia, P. Leonetti, y A. Ciancio. 2004. Alteraciones histopatológicas causadas por Meloidogyne incognita en almendro (Prunus amygdalus) 34:257-261. 
Sauter, M. 2013. Root responses to flooding. Current Opinion in Plant Biology 16:282-286.

Schmidt, W. 2003. Iron solutions: acquisition strategies and signaling pathways in plants. Trends in Plant Science 8:188-193.

Shi, Y., and D.H. Byrne. 1995. Tolerance of Prunus rootstock to potassium carbonate-induced chlorosis. Journal of the American Society for Horticultural Science 120:283-285.

Sofo, A., A.C. Tuzio, B. Dichio, and C. Xiloyannis. 2005. Influence of water deficit and rewatering on the components of the ascorbate-glutathione cycle in four interspecific Prunus hybrids. Plant Science 169:403-412.

Solari, L.I., S. Johnson, and T.M. DeJong. 2006a. Hydraulic conductance characteristics of peach (Prunus persica) trees on different rootstocks are related to biomass production and distribution. Tree Physiology 26:1343-1350.

Solari, L.I., S. Johnson, and T.M. DeJong. 2006b. Relationship of water status to vegetative growth and leaf gas exchange of peach (Prunus persica) trees on different rootstocks. Tree Physiology 26:1333-1341.

Sorce, C., R. Massai, P. Picciarelli, and R. Lorenzi. 2002. Hormonal relationships in xylem sap of grafted and ungrafted Prunus rootstocks. Scientia Horticulturae 93:333-342.

Stalin, N., G. Salesses, J. Pinochet, J. Minot, R. Voisin, and D. Esmenjaud. 1998. Comparative host suitability to Meloidogyne spp. and Pratylenchus vulnus in Myrobalan plum (Prunus cerasifera). Plant Pathology 47:211-215.

Starr, J., and C. Mercer. 2009. Development of resistant varieties. p. 326-335. In Perry, R., M. Moens, and J. Starr (eds.) Root-knot nematodes. CABI Publishing, Wallingford, Oxon, UK.

Treutter, D., and W. Feucht. 1991. Accumulation of phenolic compounds above the graft union of cherry trees. Gartenbauwissenschaft 56:134-137.

Verde, I., N. Bassil, S. Scalabrin, B. Gilmore, C.T. Lawley, K. Gasic, et al. 2012. Development and evaluation of a 9K SNP array for peach by internationally coordinated SNP detection and validation in breeding germplasm. PLoS One 7(4):e35668.

Verdejo-Lucas, S., and M. Talavera. 2009. Integrated management of nematodes parasitic on Prunus spp. p. 177-194. In Ciancio, A., and G. Mukerji (eds.) Integrated management of fruits crops and forest nematodes. Springer, Dordrecht, The Netherlands.
Vergnaud, G., and F. Denoeud. 2000. Minisatellites: Mutability and genome architecture. Genome Research 10:899-907.

Walters, S., J. Bond, J. Rusell, B. Taylor, and Z. Handoo. 2008. Incidence and influence of plant parasitic nematodes in southern Illinois peach orchards. Nematropica 38:64-74.

Webster, A.D. 1995. Rootstock and interstock effects on deciduous fruit tree vigour, precocity, and yield productivity. New Zealand Journal of Crop and Horticultural Science 23:373-382.

Whiting, J.R. 2004. Grapevine rootstocks. p. 167-188. Vol. 1. Resources. $2^{\text {nd }}$ ed. In Dry, P.R., and B.G. Coombe (eds.) Viticulture. Winetitles, Broadview, South Australia, Australia.

Xiloyannis, C., G. Celano, L. Vicinanza, D. Esmenjaud, J. GómezAparisi, G. Salesses, et al. 2002. Performance of new selections of Prunus rootstocks, resistant to root knot nematodes, in waterlogging conditions. Acta Horticulturae 658:403-405.

Yamauchi, T., S. Shimamura, M. Nakazono, and T. Mochizuki. 2013. Aerenchyma formation in crop species: A review. Field Crops Research 152:8-16.

Ye, H., W. Wang, G. Liu, L. Xhu, and K. Jia. 2009. Resistance mechanisms of Prunus rootstocks to root-knot nematode, Meloidogyne incognita. Fruits 64:295-303.

Zane, L., L. Bargelloni, and T. Patarnello. 2002. Strategies for microsatellite isolation: A review. Molecular Ecology 11:1-16

Zarrouk, O., Y. Gogorcena, J. Gómez-Aparisi, J.A. Betrán, and M.A Moreno. 2005. Influence of almond $x$ peach hybrids rootstocks on flower and leaf mineral concentration, yield and vigour of two peach cultivars. Scientia Horticulturae 106:502-514.

Zarrouk, O., Y. Gogorcena, M.A. Moreno, and J. Pinochet. 2006. Graft compatibility between peach cultivars and Prunus rootstocks. American Society for Horticultural Science 41:1389-1394.

Zhu, J-K. 2002. Salt and drought stress signal transduction in plants. Annual Review of Plant Biology 53:247-273

Ziska, L.H., T.M. DeJong, G.F. Hoffman, and R.M. Mead. 1991. Sodium and chloride distribution in salt-stressed Prunus salicina, a deciduous tree species. Tree Physiology 8:47-57.

Ziska, L.H., J.R. Seemann, and T.M. DeJong. 1990. Salinity induced limitations on photosynthesis in Prunus salicina, a deciduous tree species. Plant Physiology 93:864-870. 